\section{Regional Marketing Practices in U.S. Nursery Production}

Bridget K. Behe ${ }^{1,6}$

Department of Horticulture, Michigan State University, 238 Plant \& Soil

Sciences Building, East Lansing, MI 48824-1325

Jennifer H. Dennis ${ }^{2}$

Departments of Horticulture and Landscape Architecture and Agricultural Economics, Purdue University, West Lafayette, IN 47907

Charles R. Hall ${ }^{3}$

Department of Horticultural Sciences, Texas A\&M University, 202 Horticulture/Forest Science Building, College Station, TX 77843-2133

Alan W. Hodges ${ }^{4}$

Department of Food and Resource Economics, University of Florida, 1115 McCarty Hall, Gainesville, FL 32611

\section{Robin G. Brumfield ${ }^{5}$}

Department of Agriculture, Food, and Resource Economics, Rutgers University, 55 Dudley Rd., New Brunswick, NJ 08901-8520

Additional index words. marketing, survey, woody plant, floriculture

Abstract. Nursery production contributed \$18.1 billion to the U.S. economy in 2002 and created nearly two million jobs. A U.S. Department of Agriculture multistate research committee on economics and marketing has conducted The National Nursery Survey four times at 5-year intervals $(1988,1993,1998$, and 2003) to help fill the void of publicly available information on production, marketing, and management for the nursery industry. In 2003, the committee conducted the National Nursery Survey using a standard sampling methodology targeting 15,588 total firms representing 44 states with 2,485 nurseries responding. The objective of this analysis was to provide a regional profile of the marketing practices of nursery producers. Regional differences were present in several areas of sales management, selling practices, pricing, and advertising. Generally, the coastal regions had a higher percentage of wholesale sales, whereas interior regions had a higher percentage of retail sales. Newsletters and yellow pages were the most important form of advertising in the Great Plains; trade journals were the most important method in the south central and southeast regions; and catalogs were the most important advertising method for all other regions. The percentage of sales to repeat customers varied from a low of $65.6 \%$ in the Great Plains to a high of $76.2 \%$ in the southeast. The Appalachian (26.9\%) and southeast $(\mathbf{2 6 . 8 \%})$ regions had the highest percentage of negotiated sales, whereas the northeast had the lowest. Although significant differences generally existed among regions in the percentage of sales spent on various transaction methods, nurseries in all regions used in-person, telephone, and mail order as their three most important sales transaction methods, except for the southeast where trade shows were the third most important method of sales transactions. Landscape professionals, rewholesalers, and single-location garden centers were the major market outlets in all regions. Respondents in all regions identified production, personnel, and marketing as limitations for expansion.

Received for publication 11 July 2008. Accepted for publication 1 Aug. 2008.

The National Nursery Survey was conducted by the Green Industry Research Consortium (S-1021 Multi-state Research Committee), a group of agricultural economists and horticulturists from 24 land-grant institutions in the United States. The survey was coordinated by John Brooker (Professor Emeritus) at the University of Tennessee. The Consortium thanks financial supporters of this study: USDA-Forest Service, National Urban and Community Forestry Advisory Committee, Horticulture Research Institute, and American Nursery and Landscape Association.

${ }^{1}$ Professor.

${ }^{2}$ Assistant Professor.

${ }^{3}$ Professor and Ellison Endowed Chair for International Floriculture.

${ }^{4}$ Extension Specialist.

${ }^{5}$ Professor and Specialist in Farm Management.

${ }^{6}$ To whom reprint requests should be addressed; e-mail behe@msu.edu
In 2002, the U.S. Green Industry, which includes nursery and greenhouse producers, landscape services firms, and wholesale and retail distributors, contributed $\$ 147.8$ billion (bn; 2004 dollars) in output (sales), $\$ 95.1$ bn in value-added impacts (income) to the nation's economy, and created employment for 1.96 million $(\mathrm{mn})$ people (Hall et al., 2006). Nursery and greenhouse production was among the largest green industry sectors in terms of employment impacts $(2,621,408$ jobs) and value-added impacts ( $\$ 18.1$ bn) followed by landscaping services $(704,875$ jobs, \$35.6 bn), lawn and garden stores (347,916 jobs, $\$ 14.8$ bn), florists $(200,451$ jobs, $\$ 4.0 \mathrm{bn}$ ), and building material supply stores (123,591 jobs, $\$ 6.5$ bn). California, Florida, Oregon, and Washington are the leading states in wholesale value of production (USDA, National Ag Statistics Service, 2007).

Production of nursery crops, comprised mainly of plants with woody stems, is a substantial part of the nursery and greenhouse sector. The gross wholesale value of nursery plants in 2006 in 17 states surveyed was $\$ 4.65$ bn with 7292 producers and 471,106 acres in production (USDA, National Ag Statistics Service, 2007b). Four product categories accounted for $58 \%$ of nursery production: broadleaf evergreens ( $\$ 839 \mathrm{mn}$ ), deciduous shrubs ( $\$ 648 \mathrm{mn}$ ), deciduous flowering trees ( $\$ 584 \mathrm{mn})$, and evergreen conifers (\$562 mn).

Floriculture crop production was valued at $\$ 4$ bn wholesale in 2006, a slight decrease from production value in 2005 (USDA, National Ag Statistics Service, 2007a). Floral crops included bedding and garden plants $(\$ 1.79$ bn), potted flowering plants $(\$ 630$ $\mathrm{mn})$, potted herbaceous perennials $(\$ 507$ $\mathrm{mn})$, foliage plants $(\$ 543 \mathrm{mn})$, cut flowers $(\$ 411 \mathrm{mn})$, propagation materials $(\$ 363 \mathrm{mn})$, flowering hanging baskets $(\$ 188 \mathrm{mn})$, and cultivated florist greens ( $\$ 109 \mathrm{mn})$.

Although the USDA National Agriculture Statistics Service annually surveys floriculture producers in 34 states and triennially surveys nursery and floral crop producers in 17 states to assess production volumes and values, they do not collect information on marketing practices nor do they make regional comparisons. Our objective was to explore the regional marketing practices of U.S. commercial nurseries to determine whether there were geographic differences. For our analysis, we use "nursery" to include all producers in the green industry, i.e., nursery and greenhouse producers. We hypothesized that marketing practices differ across regions of the United States in response to agroclimatic and socioeconomic factors, giving different competitive advantages to producers in different locations. Marketing practices we examined in this article include sales through computer and other methods, sales through various marketing venues, sales to repeat customers, negotiated sales, domestic and international trade, sales at wholesale and retail, factors of price determination, factors limiting expansion, and expenditures for advertising. 


\section{Materials and Methods}

Our research committee compiled a listing of over 38,000 U.S. nursery firms in 44 states from state nursery or Green Industry trade associations and phytosanitary regulatory agencies. Because lists were not available or other surveys were ongoing, we did not survey the states of Alaska, Alabama, Arizona, Wisconsin, Kansas, and Maryland. We stratified firms on the list in four size classes based on production area or inventory of plants. Our sample of 15,588 firms included $100 \%$ of the large firms (20 or more acres production area), a random selection of $60 \%$ of the medium-sized ( 5 to 19 acres) and small-sized ( 1 to 4 acres) firms, and $40 \%$ of firms of undetermined size (see Hodges et al., 2008 for more detailed methodology).

Questions in the National Nursery Survey evolved over time to reflect industry changes. For example, we revised questions about market channels to capture sales made to massmerchandisers or chain stores, home centers, multiple-location garden centers, and rewholesalers. Brooker et al. (2005) gives wording of specific questions. We mailed survey questionnaires and asked respondents to return them to the University of Tennessee for data coding and analysis. A total of 2485 firms responded to the survey, representing a response rate of $15.9 \%$. Hodges et al. (2008) reported information on full- and part-time employment as well as annual sales. We collected annual sales as an approximate value or as a range of values with a point estimate at the midpoint or average of the sales range.

Our focus of interest in this study was the presence of regional differences in marketing practices. The eight geographic regions we analyzed using pooled state data were: Appalachia, Great Plains, midwest, mountain, northeast, Pacific, south central, and southeast. These regions broadly represent agroclimatic zones, subject to state boundaries, and closely correspond to the USDA "Farm Production Regions". We evaluated differences in mean values for survey results across regions using Duncan's multiple range test with Statistica software (StatSoft, Tulsa, OK).

\section{Results}

Florida (19.1\%) had the highest percentage of survey returns followed by New York (7.1\%), Pennsylvania (6.3\%), Oregon $(6.0 \%)$, California $(5.2 \%)$, and Ohio $(4.9 \%)$, thus showing good representation from key production areas.

Overwhelmingly, the nurseries surveyed $(98.1 \%)$ operated a nursery in only one state. The mean age of nursery businesses was 23.6 years, representing a range of new to longestablished companies. Nursery sales in 2003 reported by survey respondents totaled $\$ 2.73$ bn, which represented mean sales of $\$ 1.15$ $\mathrm{mn}$ per firm. Over half $(55 \%)$ of firms had sales of less than $\$ 250,000,21 \%$ of firms had sales of $\$ 250,000$ to $\$ 999,000,18 \%$ had sales of $\$ 1$ to $\$ 9 \mathrm{mn}$, and $2.3 \%$ had sales $\$ 10 \mathrm{mn}$ or more. Approximately $4.5 \%$ of firms did not provide sales information. Firms with at least $\$ 1 \mathrm{mn}$ in sales represented $20 \%$ of respondents and accounted for $88 \%$ of total sales reported. This distribution in sales illustrates the diversity of companies included in these results.

Selling methods. We asked several questions about selling methods, including information on domestic sales, sales at wholesale versus retail, market outlets, types of sales transactions, and repeat customers. Overall, $8.7 \%$ of firms exported to international markets, representing $0.61 \%$ of total sales. More nurseries in the Pacific region exported plants ( $1.8 \%$ of total sales) compared with firms in other regions $(P<0.05)$

Nurseries could sell at wholesale, retail, or both. Nationwide, $36.4 \%$ of the surveyed firms sold plants only at wholesale and $18.9 \%$ sold only at retail, whereas $\approx 45 \%$ of nurseries had a mix of wholesale and retail sales. The mean percentage of wholesale sales ranged from $30.7 \%$ in the Great Plains region to $74.2 \%$ in the southeast (Table 1). Nurseries in the Appalachian $(66.6 \%)$ and Pacific $(64.6 \%)$ regions also had a high mean percentage of sales at wholesale. Generally, the coastal regions nurseries had a higher percentage of wholesale sales compared with interior regions. Retail sales as a percentage of total sales were highest in the Great Plains region $(67.2 \%)$ followed by the midwest $(52.8 \%)$, northeast $(50.4 \%)$, mountain $(49.0 \%)$, and south central $(43.7 \%)$ regions. Mean retail sales were lower for the Pacific (34.6\%), Appalachian (32.6\%), and southeast $(23.1 \%)$ regions. The higher share of sales at retail for firms in the interior regions may be attributable in part to their location in areas of lower population density.

Nursery firms sold plants through a variety of outlets. Sales to landscape companies accounted for the greatest percentage of wholesale sales $(30.7 \%)$ in all regions, except the Pacific region (Table 2). Nurseries in the midwest $(41.2 \%)$ had the highest mean percentage of sales to landscape companies of any region, statistically similar to nurseries in the mountain $(36.1 \%)$, southeast $(33.7 \%)$, and Appalachian (32.3\%) regions. Nurseries in the Pacific $(15.4 \%)$ region had a lower mean share of sales to landscape companies than other regions. Generally, the second largest customer group was rewholesalers. Producers in the Pacific (30.1\%) and southeast $(30.0 \%)$ regions had the highest percentage of sales to rewholesalers, whereas nurseries in the mountain $(10.3 \%)$, midwest $(15.2 \%)$, and northeast $(15.9 \%)$ had the lowest. Garden centers with one location $(14.4 \%)$ were generally the third largest type of customer. Nurseries in the northeast $(20.2 \%)$ and Great Plains (18.9\%) had the highest sales to single-location garden centers, whereas nurseries in the midwest $(11.4 \%)$ and southeast $(11.2 \%)$ had the lowest. Sales to mass-merchandisers accounted for less than $10 \%$ of sales. Growers in the Pacific $(8.5 \%)$ region had the highest percentage of sales to mass-merchants, whereas nurseries in the midwest (1.1\%) and Great
Table 1. Sales at wholesale and at retail by surveyed nurseries in eight regions of the United States, 2003.

\begin{tabular}{lcc}
\hline Region & $\begin{array}{c}\text { Percent } \\
\text { of sales at } \\
\text { wholesale }\end{array}$ & $\begin{array}{c}\text { Percent } \\
\text { of sales at } \\
\text { retail }\end{array}$ \\
\hline Appalachian $^{\mathrm{z}}$ & $66.6 \mathrm{a}$ & $32.6 \mathrm{de}$ \\
Great Plains $^{\mathrm{y}}$ & $30.7 \mathrm{c}$ & $67.2 \mathrm{a}$ \\
Midwest $^{\mathrm{x}}$ & $45.2 \mathrm{~b}$ & $52.8 \mathrm{~b}$ \\
Mountain $^{\mathrm{w}}$ & $48.7 \mathrm{~b}$ & $49.0 \mathrm{~b}$ \\
Northeast $^{\mathrm{v}}$ & $47.4 \mathrm{~b}$ & $50.4 \mathrm{~b}$ \\
Pacific $^{\mathrm{u}}$ & $64.6 \mathrm{a}$ & $34.6 \mathrm{~cd}$ \\
South central $^{\mathrm{t}}$ & $51.8 \mathrm{~b}$ & $43.7 \mathrm{bc}$ \\
Southeast $^{\mathrm{s}}$ & $74.2 \mathrm{a}$ & $23.1 \mathrm{e}$ \\
All regions $^{\mathrm{r}}$ & 57.0 & 40.3 \\
\hline
\end{tabular}

${ }^{\mathrm{z}}$ Kentucky, North Carolina, Tennessee, Virginia and West Virginia.

${ }^{y}$ Kansas, North Dakota, Nebraska, and South Dakota.

${ }^{x}$ Iowa, Illinois, Indiana, Michigan, Minnesota, Missouri, and Ohio.

${ }^{\text {w} C o l o r a d o, ~ I d a h o, ~ M o n t a n a, ~ N e v a d a, ~ U t a h, ~ a n d ~}$ Wyoming.

${ }^{\vee}$ Connecticut, Delaware, Massachusetts, Maine, New Hampshire, New Jersey, New York, Pennsylvania, Rhode Island, and Vermont.

"California, Hawaii, Oregon, and Washington.

tArkansas, Louisiana, New Mexico, Oklahoma, and Texas.

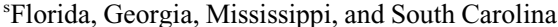
${ }^{\mathrm{r} S}$ States not surveyed were Alabama, Alaska, Arizona, Kansas, Maryland, and Wisconsin.

Table entries followed by different letters indicate statistically different values among regions $(P<$ 0.05).

Values may not add to $100 \%$ as a result of independent averaging.

Plains (1.4\%) had the lowest. Sales to multiple-location garden centers or home centers generally accounted for $5 \%$ or less of sales. Nurseries in the south central $(5.2 \%)$ region had the highest share of sales to multiplelocation garden centers. Sales to home centers averaged only $2.5 \%$ of sales and did not vary statistically across regions.

Pacific region nursery sales were very different from sales in other regions in that rewholesalers $(30.1 \%)$ were their most important outlet, whereas landscapers were the most important outlet for all other regions $(30.7 \%)$. Nurseries in the Pacific region also sold a higher percentage of products to massmerchandisers $(8.5 \%)$ when compared with other regions (3.6\%). Both of these segments historically distribute a greater volume of product than traditional free-standing garden centers.

We asked respondents to indicate the percentage of sales made by each of the following transaction methods: telephone, inperson, mail order, trade show, and Internet. Sales transactions made in-person and by telephone comprised greater than $80 \%$ of the sales made by nurseries in all regions (Table 3). In-person selling remains the predominant approach in the nursery industry. Nurseries in the midwest $(61.4 \%)$ and Great Plains $(60.9 \%)$ regions had the highest percentage of sales made in-person, whereas nurseries in the southeast $(45.3 \%)$ had the lowest. The southeastern region had the highest mean percentage of sales by telephone 
Table 2. Mean percentage of sales to various outlets by nurseries surveyed in eight regions of the United States in 2003.

\begin{tabular}{lcccccc}
\hline Region & $\begin{array}{c}\text { Single-location } \\
\text { garden center }\end{array}$ & $\begin{array}{c}\text { Multiple-location } \\
\text { garden center }\end{array}$ & $\begin{array}{c}\text { Home } \\
\text { center }\end{array}$ & Mass-merchant & Landscape & Rewholesaler \\
\hline Appalachian $^{\mathrm{z}}$ & $16.3 \mathrm{ab}$ & $4.1 \mathrm{ab}$ & $3.5 \mathrm{a}$ & $5.3 \mathrm{bcd}$ & $32.3 \mathrm{abc}$ & $21.8 \mathrm{a}$ \\
Great Plains $^{\mathrm{y}}$ & $18.9 \mathrm{~b}$ & $1.8 \mathrm{a}$ & $1.7 \mathrm{a}$ & $1.4 \mathrm{a}$ & $30.4 \mathrm{ab}$ & $18.8 \mathrm{a}$ \\
Midwest $^{\mathrm{x}}$ & $11.4 \mathrm{a}$ & $2.6 \mathrm{a}$ & $0.6 \mathrm{a}$ & $1.1 \mathrm{a}$ & $41.2 \mathrm{c}$ & $15.2 \mathrm{ab}$ \\
Mountain $^{\mathrm{w}}$ & $14.6 \mathrm{ab}$ & $2.2 \mathrm{a}$ & $1.4 \mathrm{a}$ & $6.7 \mathrm{~cd}$ & $36.1 \mathrm{bc}$ & $10.3 \mathrm{~b}$ \\
Northeast $^{\mathrm{v}}$ & $20.2 \mathrm{~b}$ & $2.9 \mathrm{ab}$ & $2.0 \mathrm{a}$ & $1.9 \mathrm{ab}$ & $30.9 \mathrm{ab}$ & $15.9 \mathrm{ab}$ \\
Pacific $^{\mathrm{u}}$ & $15.3 \mathrm{ab}$ & $4.4 \mathrm{ab}$ & $3.5 \mathrm{a}$ & $8.5 \mathrm{~d}$ & $15.4 \mathrm{~d}$ & $30.1 \mathrm{c}$ \\
South central $^{\mathrm{t}}$ & $13.8 \mathrm{ab}$ & $5.2 \mathrm{~b}$ & $2.3 \mathrm{a}$ & $5.7 \mathrm{bcd}$ & $24.9 \mathrm{a}$ & $21.8 \mathrm{a}$ \\
Southeast $^{\mathrm{s}}$ & $11.2 \mathrm{a}$ & $2.5 \mathrm{a}$ & $3.0 \mathrm{a}$ & $3.5 \mathrm{abc}$ & $33.7 \mathrm{c}$ & $30.0 \mathrm{c}$ \\
All regions $^{\mathrm{r}}$ & 14.4 & 3.2 & 2.5 & 3.6 & 30.7 & 21.1 \\
\hline
\end{tabular}

${ }^{2}$ Kentucky, North Carolina, Tennessee, Virginia, and West Virginia.

${ }^{y}$ Kansas, North Dakota, Nebraska, and South Dakota.

'Iowa, Illinois, Indiana, Michigan, Minnesota, Missouri, and Ohio.

${ }^{\mathrm{w}}$ Colorado, Idaho, Montana, Nevada, Utah, and Wyoming.

${ }^{\vee}$ Connecticut, Delaware, Massachusetts, Maine, New Hampshire, New Jersey, New York, Pennsylvania, Rhode Island, and Vermont.

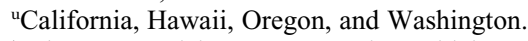

tArkansas, Louisiana, New Mexico, Oklahoma, and Texas.

${ }^{\mathrm{s}}$ Florida, Georgia, Mississippi, and South Carolina.

${ }^{\mathrm{r}}$ States not surveyed were Alabama, Alaska, Arizona, Kansas, Maryland, and Wisconsin.

Table entries followed by different letters indicate statistically different values among regions $(P<0.05)$.

Table 3. Mean percentage of sales by various transaction methods by nurseries surveyed in eight regions of the United States in 2003.

\begin{tabular}{llllcc}
\hline Region & Internet & Mail-order & In-person & Trade show & Telephone \\
\hline Appalachian $^{\mathrm{z}}$ & $2.1 \mathrm{ab}$ & $4.1 \mathrm{abc}$ & $49.1 \mathrm{ab}$ & $3.8 \mathrm{a}$ & $38.9 \mathrm{bc}$ \\
Great Plains $^{\mathrm{y}}$ & $1.0 \mathrm{a}$ & $6.4 \mathrm{c}$ & $60.9 \mathrm{~d}$ & $3.4 \mathrm{a}$ & $26.3 \mathrm{a}$ \\
Midwest $^{\mathrm{x}}$ & $1.8 \mathrm{ab}$ & $3.5 \mathrm{abc}$ & $61.4 \mathrm{~d}$ & $1.8 \mathrm{a}$ & $28.9 \mathrm{a}$ \\
Mountain $^{\mathrm{w}}$ & $2.8 \mathrm{ab}$ & $3.7 \mathrm{abc}$ & $56.2 \mathrm{bcd}$ & $2.1 \mathrm{a}$ & $32.6 \mathrm{ab}$ \\
Northeast $^{\mathrm{v}}$ & $1.8 \mathrm{ab}$ & $2.7 \mathrm{ab}$ & $59.4 \mathrm{~cd}$ & $2.1 \mathrm{a}$ & $29.1 \mathrm{a}$ \\
Pacific $^{\mathrm{u}}$ & $3.5 \mathrm{ab}$ & $5.0 \mathrm{abc}$ & $49.9 \mathrm{abc}$ & $2.7 \mathrm{a}$ & $35.1 \mathrm{ab}$ \\
South central $^{\mathrm{t}}$ & $4.3 \mathrm{~b}$ & $5.4 \mathrm{bc}$ & $50.1 \mathrm{abc}$ & $3.1 \mathrm{a}$ & $33.3 \mathrm{ab}$ \\
Southeast $^{\mathrm{s}}$ & $2.5 \mathrm{ab}$ & $1.9 \mathrm{a}$ & $45.3 \mathrm{a}$ & $3.8 \mathrm{a}$ & $44.3 \mathrm{c}$ \\
All regions & & 3.4 & 53.1 & 2.6 & 34.4
\end{tabular}

${ }^{2}$ Kentucky, North Carolina, Tennessee, Virginia, and West Virginia.

${ }^{y}$ Kansas, North Dakota, Nebraska, and South Dakota.

${ }^{\mathrm{x}}$ Iowa, Illinois, Indiana, Michigan, Minnesota, Missouri, and Ohio.

${ }^{\mathrm{w} C}$ Colorado, Idaho, Montana, Nevada, Utah, and Wyoming.

${ }^{\mathrm{v}}$ Connecticut, Delaware, Massachusetts, Maine, New Hampshire, New Jersey, New York, Pennsylvania, Rhode Island, and Vermont.

"California, Hawaii, Oregon, and Washington.

tArkansas, Louisiana, New Mexico, Oklahoma, and Texas.

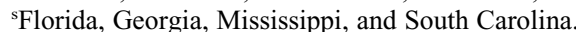

${ }^{\mathrm{r} S t a t e s ~ n o t ~ s u r v e y e d ~ w e r e ~ A l a b a m a, ~ A l a s k a, ~ A r i z o n a, ~ K a n s a s, ~ M a r y l a n d, ~ a n d ~ W i s c o n s i n ~}$

Table entries followed by different letters indicate statistically different values among regions $(P<0.05)$.

(44.3\%), similar to nurseries in the Appalachian $(38.9 \%)$ region, whereas nurseries in the northeast (29.1\%), Great Plains (26.3\%), and midwest $(28.9 \%)$ regions had the lowest sales by this medium. Nurseries in the Great Plains $(6.4 \%)$ had the highest mean percentage of sales made by mail order of any region, three times more than for nurseries in the southeast (1.9\%). Internet sales accounted for the smallest mean percentage of sales $(2.3 \%)$ across all regions except for the mountain $(2.8 \%)$, Pacific $(3.5 \%)$, south central $(4.3 \%)$, and southeast $(2.5 \%)$.

Trade shows have traditionally been an important marketing tool in the nursery industry. Expenditures on trade show advertising were consistent across regions, averaging $2.6 \%$ of sales. Nurseries typically sent representatives to one trade show in the year before the study. Mean trade show attendance with an exhibit ranged from zero to 12 with a median of 0.8. Nurseries in the Appalachian region had representatives at the highest mean number of trade shows with an exhibit
(1.2), whereas firms in the Great Plains sent representatives to the fewest mean number of trade shows $(0.3)$.

Nurseries in the Appalachian region had the highest mean percentage of sales negotiated for price and terms $(26.9 \%)$, which was similar for nurseries in the southeast $(26.8 \%)$, Pacific $(24.5 \%)$, and south central $(20.8 \%)$ regions (Table 4). Nurseries in the northeast had the lowest mean percentage of negotiated sales $(12.7 \%)$, which was similar to nurseries in the midwest $(17.2 \%)$ and mountain (18.8\%) regions.

A measure of customer loyalty is the percentage of sales to repeat customers. Nurseries in the Appalachian region had the highest mean percentage of repeat sales $(76.2 \%)$ followed by nurseries in the southeast $(73.8 \%)$, mountain $(73.8 \%)$, and Pacific $(72.9 \%)$ regions. Nurseries in the Great Plains had the lowest percentage of sales to repeat customers $(65.6 \%)$, similar to nurseries in the midwest $(68.8 \%)$ region (Table 4).
Pricing, advertising, and business challenges. We asked several questions to gather details on key pricing, promotion, and business challenges. Nurseries rated eight factors contributing to the determination of price in terms of their relative importance using a 4-point scale with $1=$ not important to $4=$ very important (Table 5). Production cost (3.27) had higher mean ratings than other factors contributing to price determination in all regions except for the mountain (3.33) and northeast (3.27) regions where it was the second most important factor contributing to price determination. Plant grade (3.14) was the second most important factor in price determination in all regions except for mountain (3.36) and northeast (3.20) where it was the most important factor. Ratings for plant grade were statistically slightly higher for nurseries in the mountain region compared with the Pacific (3.05) and Great Plains (3.02) regions. Market demand (2.99) received equal and moderately high mean ratings making it the third most important factor in price determination for nurseries throughout the United States. Inventory level (2.41) received equal and slightly lower but statistically similar mean ratings in all regions. Product uniqueness (2.79) received similar mean ratings from nurseries in all regions except for slightly lower ratings in the Great Plains (2.31). Prices of other nurseries' products had a lower mean rating for nurseries in the Great Plains (2.42) compared with other regions (2.72). Last year's prices (2.33) had a higher mean rating from nurseries in the Appalachian (2.55) and midwest (2.49) regions compared with the southeast (2.14). Inflation (2.00) received the lowest mean ratings of any factor from nurseries throughout the country, but they were lowest for nurseries in the Great Plains (1.81) and south central (1.87) regions, and slightly higher for nurseries in the Appalachian (2.18) region.

Tremendous variability existed in the mean percentage of sales spent on various forms of advertising (Table 6). Catalog advertising varied from a low in the southeast $(7.0 \%)$ and Great Plains (7.8\%) to a high of $15.4 \%$ in the midwest. Respondents in the Appalachian (15.1\%), midwest (15.4\%), mountain $(14.8 \%)$, northeast $(14.6 \%)$, and Pacific (12.0\%) regions spent more on cata$\log$ advertising as a percentage of total sales than any other form of advertising. The yellow pages were the major form of advertising for respondents in the Great Plains region $(13.0 \%)$ and the second form of advertising in the mountain $(13.5 \%)$, midwest $(12.1 \%)$, south central $(12.4 \%)$, and northeast $(7.1 \%)$, regions. The mean percent of total sales spent on newsletter advertising was similarly moderate in every region except the Great Plains (13.0\%) where it was the most important type of advertising. Respondents in the southeast $(14.1 \%)$ and south central $(13.5 \%)$ regions spent more on trade journal advertising as a percentage of total sales than any other form of advertising. This was statistically similar to expenditures in the Appalachian region (14.5\%) where it 
Table 4. Sales to repeat customers and sales negotiated by surveyed nurseries in eight regions of the United States, 2003.

\begin{tabular}{|c|c|c|}
\hline Region & $\begin{array}{c}\text { Percent } \\
\text { of sales to } \\
\text { repeat customers }\end{array}$ & $\begin{array}{c}\text { Percent } \\
\text { of sales } \\
\text { negotiated }\end{array}$ \\
\hline Appalachian $^{z}$ & $76.2 \mathrm{a}$ & $26.9 \mathrm{a}$ \\
\hline Great Plains $^{y}$ & $65.6 \mathrm{c}$ & $20.0 \mathrm{abc}$ \\
\hline Midwest $^{\mathrm{x}}$ & $68.8 \mathrm{bc}$ & $17.2 \mathrm{bc}$ \\
\hline Mountain ${ }^{w}$ & $73.8 \mathrm{ab}$ & $18.2 \mathrm{bc}$ \\
\hline Northeast $^{\mathrm{v}}$ & $71.9 \mathrm{abc}$ & $12.7 \mathrm{c}$ \\
\hline Pacific $^{u}$ & $72.9 \mathrm{ab}$ & $24.5 \mathrm{ab}$ \\
\hline South central ${ }^{\mathrm{t}}$ & $71.1 \mathrm{abc}$ & $20.8 \mathrm{ab}$ \\
\hline Southeast $\mathrm{s}^{\mathrm{s}}$ & $73.8 \mathrm{ab}$ & $26.8 \mathrm{a}$ \\
\hline All regions ${ }^{\mathrm{r}}$ & 71.1 & 20.8 \\
\hline
\end{tabular}

${ }^{\mathrm{z}}$ Kentucky, North Carolina, Tennessee, Virginia, and West Virginia.

${ }^{y}$ Kansas, North Dakota, Nebraska, and South Dakota.

'Iowa, Illinois, Indiana, Michigan, Minnesota, Missouri, and Ohio.

${ }^{\mathrm{w}}$ Colorado, Idaho, Montana, Nevada, Utah, and Wyoming.

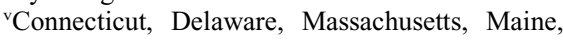
New Hampshire, New Jersey, New York, Pennsylvania, Rhode Island, and Vermont.

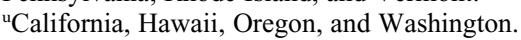

tArkansas, Louisiana, New Mexico, Oklahoma, and Texas.

${ }^{\text {s} F l o r i d a, ~ G e o r g i a, ~ M i s s i s s i p p i, ~ a n d ~ S o u t h ~ C a r o l i n a . ~}$ ${ }^{r}$ States not surveyed are Alabama, Alaska, Arizona, Kansas, Maryland, and Wisconsin.

Table entries followed by different letters indicate statistically different values among regions $(P$ $<0.05)$.

was the second most important type of advertising in terms of mean percent of total sales. Web site advertising received the next highest mean percentage of total sales, with the least amount spent in the Great Plains $(2.1 \%)$ and the most spent in the Pacific region $(6.8 \%)$. Radio and television advertising varied from a low of $1.1 \%$ of total sales in the Pacific region to a high of $10.9 \%$ in the Great Plains region. One form of advertising that did not vary statistically by geographic region was the percentage of sales allocated to gardening publications, averaging $2.8 \%$ for all regions. Billboard advertising was the category with the lowest mean percentage of sales, varying from $0.1 \%$ in the southeast region to $2.4 \%$ in the Great Plains region.

We asked businesses to rate the importance of seven factors that might limit business expansion using the same 4-point scale (Table 7). There were no geographic statistical differences among regions for the mean ratings for debt capital, equity capital, marketing, personnel, and production. Each of these factors received a rating between 2.1 and 2.7 indicating a somewhat uniform and moderate level of importance to nurseries across the United States. Statistical geographic differences existed for ratings of plant offerings (2.15) and transportation (2.21). Nurseries in the Great Plains (1.94) rated plant offerings as less important than nurseries in all other regions. Nurseries in the mountain (2.49) region gave transportation as a limiting factor a higher rating compared with nurseries in the Great Plains (2.10) or northeast (2.10), whereas south central nurseries in the Pacific (2.45) region rated this factor similarly high compared with nurseries in the southcentral (2.41), southeast (2.29), Appalachian (2.37), and midwest (2.12).

Marketing as a factor limiting business expansion was statistically similar across all regions (2.39).

Summary of observations by regions. Nurseries in the Appalachian region sold the most $(66.6 \%)$ products at wholesale of all regions and a majority of product to landscape firms $(32.3 \%)$, rewholesalers $(21.8 \%)$, and single-location garden centers (16.3\%). This region had a relatively low percentage of direct retail sales $(32.6 \%)$ and had the highest percentage of sales to repeat customers (76.2\%) and negotiated sales $(26.9 \%)$, indicating some customer loyalty and the willingness to work toward a mutually acceptable price. Nurseries in the Appalachian region were represented at the greatest number of

Table 5. Factors contributing to price determination for nurseries surveyed in eight regions of the United States in 2003 .

\begin{tabular}{lllllllll}
\hline & \multicolumn{3}{c}{$\begin{array}{c}\text { Last year's } \\
\text { price }\end{array}$} & $\begin{array}{c}\text { Market } \\
\text { demand }\end{array}$ & $\begin{array}{c}\text { Others' } \\
\text { prices }\end{array}$ & $\begin{array}{c}\text { Plant } \\
\text { grade }\end{array}$ & $\begin{array}{c}\text { Product } \\
\text { uniqueness }\end{array}$ & $\begin{array}{c}\text { Production-level } \\
\text { cost }\end{array}$ \\
\hline Appalachian $^{\mathrm{z}}$ & $2.18 \mathrm{~b}$ & $2.54 \mathrm{a}$ & $2.55 \mathrm{a}$ & $3.05 \mathrm{a}$ & $2.79 \mathrm{~b}$ & $3.27 \mathrm{ab}$ & $2.77 \mathrm{~b}$ & $3.42 \mathrm{ab}$ \\
Great Plains $^{\mathrm{y}}$ & $1.81 \mathrm{a}$ & $2.27 \mathrm{a}$ & $2.31 \mathrm{abc}$ & $2.88 \mathrm{a}$ & $2.42 \mathrm{a}$ & $3.02 \mathrm{a}$ & $2.31 \mathrm{a}$ & $3.27 \mathrm{ab}$ \\
Midwest $^{\mathrm{x}}$ & $2.10 \mathrm{ab}$ & $2.48 \mathrm{a}$ & $2.49 \mathrm{a}$ & $3.02 \mathrm{a}$ & $2.74 \mathrm{~b}$ & $3.14 \mathrm{ab}$ & $2.78 \mathrm{~b}$ & $3.15 \mathrm{a}$ \\
Mountain $^{\mathrm{w}}$ & $2.07 \mathrm{ab}$ & $2.42 \mathrm{a}$ & $2.40 \mathrm{abc}$ & $3.02 \mathrm{a}$ & $2.80 \mathrm{~b}$ & $3.36 \mathrm{~b}$ & $2.82 \mathrm{~b}$ & $3.33 \mathrm{ab}$ \\
Northeast $^{\mathrm{v}}$ & $2.09 \mathrm{ab}$ & $2.42 \mathrm{a}$ & $2.46 \mathrm{ac}$ & $2.97 \mathrm{a}$ & $2.63 \mathrm{~b}$ & $3.20 \mathrm{ab}$ & $2.87 \mathrm{~b}$ & $3.27 \mathrm{ab}$ \\
Pacific $^{\mathrm{u}}$ & $2.06 \mathrm{ab}$ & $2.34 \mathrm{a}$ & $2.31 \mathrm{abc}$ & $3.00 \mathrm{a}$ & $2.86 \mathrm{~b}$ & $3.05 \mathrm{a}$ & $2.85 \mathrm{~b}$ & $3.31 \mathrm{ab}$ \\
South central $^{\mathrm{t}}$ & $1.87 \mathrm{a}$ & $2.49 \mathrm{a}$ & $2.20 \mathrm{bc}$ & $3.11 \mathrm{a}$ & $2.61 \mathrm{ab}$ & $3.08 \mathrm{ab}$ & $2.80 \mathrm{~b}$ & $3.52 \mathrm{~b}$ \\
Southeast $^{\mathrm{s}}$ & $1.91 \mathrm{ab}$ & $2.41 \mathrm{a}$ & $2.14 \mathrm{~b}$ & $3.09 \mathrm{a}$ & $2.79 \mathrm{~b}$ & $3.19 \mathrm{ab}$ & $2.80 \mathrm{~b}$ & $3.38 \mathrm{ab}$ \\
All regions $^{\mathrm{r}}$ & 2.00 & 2.41 & 2.33 & 2.99 & 2.72 & 3.14 & 2.79 & 3.27 \\
\hline
\end{tabular}

${ }^{\mathrm{z} K e n t u c k y, ~ N o r t h ~ C a r o l i n a, ~ T e n n e s s e e, ~ V i r g i n i a, ~ a n d ~ W e s t ~ V i r g i n i a . ~}$

${ }^{y}$ Kansas, North Dakota, Nebraska, and South Dakota.

'xowa, Illinois, Indiana, Michigan, Minnesota, Missouri, and Ohio.

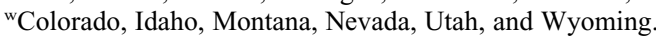

${ }^{\vee}$ Connecticut, Delaware, Massachusetts, Maine, New Hampshire, New Jersey, New York, Pennsylvania, Rhode Island, and Vermont.

"California, Hawaii, Oregon, and Washington.

tArkansas, Louisiana, New Mexico, Oklahoma, and Texas.

sFlorida, Georgia, Mississippi, and South Carolina.

${ }^{r}$ States not surveyed were Alabama, Alaska, Arizona, Kansas, Maryland, and Wisconsin.

Rating made on a 4-point scale where $4=$ very important, $1=$ not important.

Table entries followed by different letters indicate statistically different values among regions $(P<0.05)$. trade shows, likely where they could interact with the customers from their core market segments. Key factors determining price for Appalachian nurseries were production cost (3.42) and plant grade (3.27), but both of these were ranked higher by some other regions. Most sales transactions were made in-person $(49.1 \%)$ or by telephone $(38.9 \%)$. Appalachian nurseries spent more on their two most important forms of advertising, catalogs $(15.1 \%)$ and trade journals (14.5\%), than did other regions. Similar to other regions, production (2.69), personnel (2.70), and marketing (2.63) were the top three factors limiting expansion.

Nurseries in the Great Plains region had a larger percentage of retail sales $(67.3 \%)$ than any other region. Nurseries in the Great Plains region sold a majority of product to landscape firms (30.4\%), single-location garden centers $(18.9 \%)$, and rewholesalers (18.8\%). Like Appalachian nurseries, of greatest importance to determine price were production cost (3.27) and plant grade (3.02), likely because these factors are critical to the success of their customers. Key factors limiting expansion were production (2.64), marketing (2.58), and personnel (2.56). Most sales transactions were made in-person $(60.9 \%)$, high relative to other regions, and by telephone $(26.3 \%)$, the lowest of any region. Primary advertising methods were newsletters $(13.4 \%)$, the highest in any region, and yellow pages $(13.0 \%)$. In this region like in the Appalachian region, print advertising was of greater importance than other types of advertising. Nurseries in the Great Plains region had the lowest percentage of sales to repeat customers $(65.5 \%)$ of any region and a moderate percentage of negotiated sales $(20.0 \%)$ compared with other regions.

Sales for nurseries in the midwest were somewhat evenly split between wholesale $(45.2 \%)$ and retail $(52.8 \%)$. Nurseries in the midwest region had the largest sales volume of any region to landscape firms $(41.2 \%)$ and the lowest volume of any region to singlelocation garden centers $(11.4 \%)$. Their second most important sales outlet was to rewholesalers $(18.8 \%)$. Ratings of factors limiting expansion were highest for personnel (2.53) and production (2.50), similar to other regions. Like in the Great Plains region, most sales transactions were made in-person $(61.4 \%)$, the highest of any region, and by telephone $(28.9 \%)$, low compared with other regions. Key factors determining price for midwest nurseries were production cost (3.15), which was higher than many other regions, and plant grade (3.14). Primary advertising methods were catalog (15.4\%), the highest of any region, and yellow pages $(12.1 \%)$, a moderate amount compared with other regions. Again, we observed a relatively greater importance of print media advertising. Nurseries in the midwest region had a moderate percentage of sales to repeat customers $(68.8 \%)$ and a moderate percentage of negotiated sales (17.2\%) compared with other regions. 
Table 6. Expenditures on advertising forms as a percentage of sales by nurseries surveyed in eight regions of the United States in 2003.

\begin{tabular}{|c|c|c|c|c|c|c|c|c|}
\hline Region & Billboard & $\begin{array}{c}\text { Catalog } \\
\text { print or } \\
\text { compact disk }\end{array}$ & $\begin{array}{l}\text { Gardening } \\
\text { publication }\end{array}$ & Newsletters & $\begin{array}{l}\text { Radio or } \\
\text { television }\end{array}$ & $\begin{array}{c}\text { Trade } \\
\text { journals }\end{array}$ & $\begin{array}{l}\text { Web } \\
\text { sites }\end{array}$ & $\begin{array}{c}\text { Yellow } \\
\text { pages }\end{array}$ \\
\hline Appalachian ${ }^{2}$ & $1.5 \mathrm{ab}$ & $15.1 \mathrm{a}$ & $2.4 \mathrm{a}$ & $5.1 \mathrm{a}$ & $3.4 \mathrm{ab}$ & $14.5 \mathrm{~b}$ & $5.8 \mathrm{ab}$ & $9.1 \mathrm{abc}$ \\
\hline Great Plains ${ }^{y}$ & $2.4 \mathrm{~b}$ & $7.8 \mathrm{~b}$ & $2.0 \mathrm{a}$ & $13.0 \mathrm{~b}$ & $10.9 \mathrm{c}$ & $6.0 \mathrm{a}$ & $2.1 \mathrm{a}$ & $13.0 \mathrm{a}$ \\
\hline Midwest $^{\mathrm{x}}$ & $1.6 \mathrm{ab}$ & $15.4 \mathrm{a}$ & $1.3 \mathrm{a}$ & $6.7 \mathrm{a}$ & $5.7 \mathrm{~b}$ & $5.1 \mathrm{a}$ & $4.1 \mathrm{ab}$ & $12.1 \mathrm{ac}$ \\
\hline Mountainw & $0.4 \mathrm{ab}$ & $14.8 \mathrm{a}$ & $1.6 \mathrm{a}$ & $5.1 \mathrm{a}$ & $10.7 \mathrm{c}$ & $6.7 \mathrm{a}$ & $6.1 \mathrm{ab}$ & $13.5 \mathrm{a}$ \\
\hline & & 1 & $\mathrm{a}$ & $6.6 \mathrm{a}$ & $3.4 \mathrm{ab}$ & $5.1 \mathrm{a}$ & $5.0 \mathrm{ab}$ & $7.1 \mathrm{bc}$ \\
\hline Pacif & $5 \mathrm{ab}$ & $12.0 \mathrm{ab}$ & $2.9 \mathrm{a}$ & $7.5 \mathrm{a}$ & $1.1 \mathrm{a}$ & $10.6 \mathrm{ab}$ & $6.8 \mathrm{~b}$ & $6.3 \mathrm{~b}$ \\
\hline th central ${ }^{t}$ & $0.9 \mathrm{ab}$ & $9.3 \mathrm{ab}$ & $3.6 \mathrm{a}$ & $4.0 \mathrm{a}$ & $5.2 \mathrm{~b}$ & $13.5 \mathrm{~b}$ & $4.6 \mathrm{ab}$ & $12.4 \mathrm{ac}$ \\
\hline Southeast ${ }^{s}$ & $0.1 \mathrm{a}$ & $7.0 \mathrm{~b}$ & $3.5 \mathrm{a}$ & $4.8 \mathrm{a}$ & $1.7 \mathrm{a}$ & $14.1 \mathrm{~b}$ & $5.8 \mathrm{ab}$ & $6.2 \mathrm{~b}$ \\
\hline All regions ${ }^{r}$ & 1.0 & 11.2 & 2.8 & 6.0 & 3.6 & 5.4 & 4.9 & 8.3 \\
\hline
\end{tabular}

${ }^{\mathrm{z}}$ Kentucky, North Carolina, Tennessee, Virginia, and West Virginia.

${ }^{y}$ Kansas, North Dakota, Nebraska, and South Dakota.

${ }^{x}$ Iowa, Illinois, Indiana, Michigan, Minnesota, Missouri, and Ohio.

${ }^{\mathrm{w} C}$ Colorado, Idaho, Montana, Nevada, Utah, and Wyoming.

${ }^{\mathrm{v}}$ Connecticut, Delaware, Massachusetts, Maine, New Hampshire, New Jersey, New York, Pennsylvania, Rhode Island, and Vermont.

"California, Hawaii, Oregon, and Washington.

tArkansas, Louisiana, New Mexico, Oklahoma, and Texas.

${ }^{\text {s}}$ Florida, Georgia, Mississippi, and South Carolina.

${ }^{\mathrm{r}}$ States not surveyed were Alabama, Alaska, Arizona, Kansas, Maryland, and Wisconsin.

Table entries followed by different letters indicate statistically different values among regions $(P<0.05)$.

Table 7. Factors limiting expansion for nurseries surveyed in eight regions of the United States in 2003.

\begin{tabular}{lccccccc}
\hline Region & $\begin{array}{c}\text { Debt } \\
\text { capital }\end{array}$ & $\begin{array}{c}\text { Equity } \\
\text { capital }\end{array}$ & Marketing & Personnel & $\begin{array}{c}\text { Plant } \\
\text { offering }\end{array}$ & Production & Transportation \\
\hline Appalachian $^{\mathrm{z}}$ & $2.28 \mathrm{a}$ & $2.24 \mathrm{a}$ & $2.63 \mathrm{a}$ & $2.70 \mathrm{a}$ & $2.20 \mathrm{ab}$ & $2.69 \mathrm{a}$ & $2.37 \mathrm{abc}$ \\
Great Plains $^{\mathrm{y}}$ & $2.25 \mathrm{a}$ & $2.19 \mathrm{a}$ & $2.58 \mathrm{a}$ & $2.56 \mathrm{a}$ & $1.94 \mathrm{~b}$ & $2.64 \mathrm{a}$ & $2.10 \mathrm{a}$ \\
Midwest $^{\mathrm{x}}$ & $2.17 \mathrm{a}$ & $2.10 \mathrm{a}$ & $2.36 \mathrm{a}$ & $2.53 \mathrm{a}$ & $2.16 \mathrm{ab}$ & $2.50 \mathrm{a}$ & $2.12 \mathrm{abc}$ \\
Mountain $^{\mathrm{w}}$ & $2.40 \mathrm{a}$ & $2.28 \mathrm{a}$ & $2.57 \mathrm{a}$ & $2.63 \mathrm{a}$ & $2.22 \mathrm{ab}$ & $2.44 \mathrm{a}$ & $2.49 \mathrm{c}$ \\
Northeast $^{\mathrm{v}}$ & $2.18 \mathrm{a}$ & $2.15 \mathrm{a}$ & $2.32 \mathrm{a}$ & $2.57 \mathrm{a}$ & $2.09 \mathrm{ab}$ & $2.50 \mathrm{a}$ & $2.10 \mathrm{a}$ \\
Pacific $^{\mathrm{u}}$ & $2.15 \mathrm{a}$ & $2.14 \mathrm{a}$ & $2.54 \mathrm{a}$ & $2.46 \mathrm{a}$ & $2.31 \mathrm{a}$ & $2.62 \mathrm{a}$ & $2.45 \mathrm{bc}$ \\
South central $^{\mathrm{t}}$ & $2.29 \mathrm{a}$ & $2.20 \mathrm{a}$ & $2.47 \mathrm{a}$ & $2.56 \mathrm{a}$ & $2.32 \mathrm{a}$ & $2.67 \mathrm{a}$ & $2.41 \mathrm{abc}$ \\
Southeast $^{\mathrm{s}}$ & $2.31 \mathrm{a}$ & $2.23 \mathrm{a}$ & $2.42 \mathrm{a}$ & $2.50 \mathrm{a}$ & $2.29 \mathrm{a}$ & $2.56 \mathrm{a}$ & $2.29 \mathrm{abc}$ \\
All regions $^{\mathrm{r}}$ & 2.17 & 2.11 & 2.39 & 2.50 & 2.15 & 2.51 & 2.21 \\
\hline
\end{tabular}

${ }^{2}$ Kentucky, North Carolina, Tennessee, Virginia, and West Virginia.

${ }^{y}$ Kansas, North Dakota, Nebraska, and South Dakota.

${ }^{x}$ Iowa, Illinois, Indiana, Michigan, Minnesota, Missouri, and Ohio.

${ }^{\text {w}}$ Colorado, Idaho, Montana, Nevada, Utah, and Wyoming.

${ }^{\vee}$ Connecticut, Delaware, Massachusetts, Maine, New Hampshire, New Jersey, New York, Pennsylvania, Rhode Island, and Vermont.

"California, Hawaii, Oregon, and Washington.

t'Arkansas, Louisiana, New Mexico, Oklahoma, and Texas.

${ }^{\mathrm{s}}$ Florida, Georgia, Mississippi, and South Carolina.

${ }^{\mathrm{r}}$ States not surveyed were Alabama, Alaska, Arizona, Kansas, Maryland, and Wisconsin.

Ratings made on a 4-point scale, where $4=$ very important, $1=$ not important.

Table entries followed by different letters indicate statistically different values among regions $(P<0.05)$.

Sales for nurseries in the mountain region were somewhat evenly split between wholesale $(48.7 \%)$ and retail $(49.0 \%)$ outlets. Like in most other regions, nurseries in the mountain region sold a majority of product to landscape firms $(36.1 \%)$, single-location garden centers $(14.6 \%)$, and rewholesalers $(10.3 \%)$. Ratings of factors limiting expansion were highest for personnel (2.63) and marketing (2.57), similar to other regions; however, unlike most other regions, transportation (2.49) was the third most important factor limiting expansion. Key factors determining price for mountain region nurseries were plant grade (3.36), rated the highest of any region, and production cost (3.33), which was moderate relative to other regions. Primary advertising methods were catalog $(14.8 \%)$ and yellow pages $(13.5 \%)$, both of which were high relative to other regions. Most sales in the mountain region were made in-person (56.2\%) and by telephone (32.6\%), like most nurseries in other regions. Nurseries in the mountain region had a relatively high percentage of sales to repeat customers (73.8\%) compared with other regions and a moderate percentage of negotiated sales $(18.2 \%)$ compared with other regions.

Sales for nurseries in the northeast region were somewhat evenly split between wholesale $(47.4 \%)$ and retail $(50.4 \%)$. Nurseries in the northeast region sold a majority of product to landscape firms $(30.9 \%)$ and rewholesalers $(15.9 \%)$, both moderate relative to other regions. They sold a higher percentage of sales to single-location garden centers $(20.2 \%)$ than any other region, statistically similar to the Great Plains region $(18.9 \%)$. Ratings of factors limiting expansion were highest for personnel (2.57), production (2.50), and marketing (2.32), similar to other regions. Key factors determining price for northeastern nurseries were plant grade (3.20) and production cost (3.27), also similar to other regions. Primary methods of advertising were catalogs (14.6), among the highest percentage spent among regions, and yellow pages $(7.1 \%)$, which was among the lowest. Most sales for northeast nurseries were made in-person (59.4\%), high compared with other regions, and by telephone $(29.1 \%)$, which was relatively low compared with other regions. Nurseries in the northeast region had a moderate percentage of sales to repeat customers $(71.9 \%)$ compared with other regions and the lowest percentage of negotiated sales $(12.7 \%)$ of any region.

The majority of sales for nurseries in the Pacific region were wholesale $(64.6 \%)$. The Pacific region had a relatively high percentage of sales to repeat customers $(72.9 \%)$ and negotiated sales $(24.5 \%)$, indicating some customer loyalty and the willingness to work toward a mutually acceptable price. Nurseries in the Pacific region sold a majority of product through rewholesalers (30.1\%), which was highest among regions, and landscapers $(15.4 \%)$ and single-location garden centers $(15.3 \%)$, which were the lowest among regions. Mass-merchants were an important type of customer with $8.5 \%$ of sales. Although nurseries in the Pacific region had high wholesale and low retail sales, they had higher sales to mass-merchandisers $(8.5 \%)$ and home centers $(3.5 \%)$ than nurseries in other regions. Like nurseries in other regions, key sales methods were in-person $(49.9 \%)$ and telephone $(35.1 \%)$. The three most important factors for determining price were production cost (3.31), plant grade (3.05), and market demand (3.00). Primary methods of advertising were catalog $(12.0 \%)$ and trade journals $(10.6 \%)$, both of which were relatively high among many other regions. Ratings of factors limiting expansion were highest for production (2.62) and marketing (2.54), similar to some other regions. Like the mountain region, transportation (2.45) was the third most important factor limiting expansion in the Pacific region, probably because producers are far from their markets.

Sales for nurseries in the south central region were somewhat evenly split between wholesale $(51.8 \%)$ and retail $(43.7 \%)$. Nurseries in the south central region sold a majority of product to landscapers $(24.9 \%)$ and rewholesalers $(21.8 \%)$. Like in other regions, key sales methods were in-person $(50.1 \%)$ and on the telephone $(33.3 \%)$. Key factors determining price for nurseries in the south central region were production cost (3.52) and market demand (3.11), both higher than in any other region. Primary methods of advertising were trade journals $(13.5 \%)$ and yellow pages $(12.4 \%)$, both relatively high compared with other regions. The top three factors limiting expansion were production (2.67), personnel (2.56), and marketing (2.47), similar to other regions. The south central region had a similar percentage of sales to repeat customers $(71.1 \%)$ and negotiated sales $(20.8 \%)$ compared with other regions. 
The southeast had the highest percentage of wholesale sales $(74.2 \%)$ of any region. Nurseries in the southeast region had relatively high sales to landscape firms (33.7\%) and rewholesale firms (30.0\%) among regions. Key sales methods were in-person (45.3\%), the lowest among regions, and by telephone $(44.3 \%)$, the highest among regions. Trade show sales $(3.8 \%)$ in the southeast were the highest among regions, and mail order sales were the lowest among regions. Important factors determining price for southeastern nurseries were production cost (3.38) and plant grade (3.19). Primary advertising methods as a percentage of sales were trade journals (14.1\%), relatively high among regions, and catalog print or $\mathrm{CD}(7.0 \%)$, relatively low among regions. The top three factors limiting expansion of nurseries in the southeast region were production (2.56), personnel (2.50), and marketing (2.42), similar to other regions. The southeast region had a moderate percentage of sales to repeat customers (73.8\%) and a high percentage of negotiated sales $(26.8 \%)$ compared with other regions.

\section{Conclusions}

Results from this study show that marketing practices and expansion considerations by ornamental plant nurseries varied by geographic region in the United States. Generally, the coastal regions had a higher percentage of wholesale sales compared with interior regions, whereas interior regions had a higher percentage of retail sales as a percentage of total sales. The higher share of sales at retail for firms in the interior regions may be attributable in part to their location in areas of lower population density. Producers in these regions may tend to focus on the local market, whereas producers in other regions may find it too costly to ship their products to these markets.

In terms of markets for plants, landscape professionals, rewholesalers, and singlelocation garden centers comprise a large portion of the market. The Pacific region was the only region where rewholesalers were the major outlet, buying more than landscapers. In the northeast, Great Plains, and mountain regions, nurseries had a higher percentage of sales at single-location garden centers than through rewholesalers. Home centers, multiple-location garden centers, and mass-merchandisers buy a relatively small percentage of nursery products.

Although significant differences generally existed among regions in the percentage of sales spent on various transaction methods, all regions used in-person, telephone, and mail order as their three most important sales transaction methods, except for the southeast where trade shows were the third most important method of sales transactions.

Regions varied greatly in the expenditures on various forms of advertising. Newsletters and yellow pages were the most important form of advertising in the Great Plains, trade journals were the most important method in the south central and southeast regions, and catalogs were the most important advertising method for all other regions.

The percentage of sales to repeat customers varied from a low of $65.6 \%$ in the Great Plains to a high of $76.2 \%$ in the southeast. The Appalachian (26.9\%) and southeast $(26.8 \%)$ regions had the highest percentage of negotiated sales, whereas the northeast had the lowest percentage of negotiated sales.

Although significant differences generally existed among regions, a few categories showed no statistical differences between regions. For example, respondents in all regions identified the same limitations for expansion, which included production, personnel, and marketing. Nurseries in all regions identified production costs, plant grade, and market demand as the most important factors contributing to price determination.

Yet, the Pacific region nurseries distinguished themselves in their marketing practices in more ways than nurseries in other regions. They conducted more international trade than any other region. The main marketing outlet for nurseries in the Pacific region was rewholesaler, whereas landscapers were the primary market outlet for nurseries in all other regions. As transportation costs escalate, their climatological advantage may not persist if shipping costs outweigh lower energy costs. They were the only region that did not use yellow pages as one of their three primary forms of advertising.

These findings on regional differences are important because they may help industry managers with strategic planning and marketing decisions that move them toward a competitive advantage. Nurseries can examine their business practices vis-à-vis competitors in other regions to help determine which methods work best and where opportunities exist for future growth or change.

Cognizance of changes over time is critical to businesses in the supply chain if these firms want to adapt to meet the demands of their changing customers.

\section{Literature Cited}

Brooker, J.R., D. Eastwood, C. Hall, K. Morris, A. Hodges, and J. Haydu. 2005. Trade flows and marketing practices within the U.S. nursery industry: 2003. Southern Coop. Series Bull. 404, Univ. of Tenn. Ag. Expt. Sta.10 Sept. 2008. <http://www.cals.ncsu.edu/saaesd/scsb/ list/SCBxyz.pdf>.

Hall, C.R., A.W. Hodges, and J.J. Haydu. 2006. The economic impacts of the Green industry in the U.S. HortTechnology 16:345-353.

Hodges, A.W., C.R. Hall, B.K. Behe, and J.H. Dennis. 2008. Regional analysis of production practices and technology use in the U.S. nursery industry. HortScience 43:18071812

USDA, National Ag Statistics Service. 2007a Floriculture crops summary. 23 Apr. 2008. $<$ http://usda.mannlib.cornell.edu/usda/current/ FlorCrop/FlorCrop-07-26-2007.pdf>.

USDA, National Ag Statistics Service. 2007b. Nursery crops summary. 11 Apr. 2008. <http://usda. mannlib.cornell.edu/usda/current/NursProd/Nurs Prod-09-26-2007.pdf> 